\title{
GLOBAL ECONOMIC CRISIS AND MARKETING DEFENCE OF THE TERTIARY SECTOR
}

\author{
Miroslava Vaštíková
}

\section{Klíčová slova:}

ekonomická krize, firmy poskytující ubytovací, stravovací služby a služby v cestovním ruchu, marketingový výzkum, marketingový mix

\section{Key words:}

economic crisis, companies providing services in hotel industry, accommodation and tourism, marketing research, marketing mix

\begin{abstract}
Abstrakt
Tento příspěvek je pouhou výsečí poznatků z řešení primárního marketingového výzkumu realizovaného v rámci výuky předmětu Marketing služeb katedrou marketingu Obchodně podnikatelské fakulty v Karviné, Slezské univerzity v Opavě, v roce 2010. Zadavatele zajímalo, zda a jakým způsobem se projeví hospodářská krize na změnách marketingových strategií, vyjádřených prvky marketingového mixu, firem poskytujících služby. Pro tento př́spěvek jsme vybrali firmy, jejichž činnost napomáhá rozvoji cestovního ruchu, tj. firmy poskytující služby v oblasti pohostinství, ubytování a v cestovním ruchu. Údaje získané dotazníkovým šetřením se vztahují k počátkům krize, do konce roku 2009.
\end{abstract}

\begin{abstract}
This article reflects the basic summary of observations achieved in the primary marketing research realized within lessons of Marketing of services carried on Silesian University in Opava, OPF in Karvina in 2010. The main task of the research was to find whether and in which ways the economic crises affects marketing strategies of companies providing services. Marketing strategies shall be represented by elements of marketing mix. For needs of this article we have chosen companies whose activities help the tourist trade development, i.e. companies providing services in hotel industry, accommodation and tourism. Data achieved from this research are valid for the time period of the beginning of the economic crises, i.e. till the end of the year 2009 .
\end{abstract}

\section{Introduction}

Financial and economic crisis dated in 2008 - 2009 affected the life of numerous individuals, companies and countries. Specialists, investors, contractors as well as employees have been interested in matters which caused such crisis that started in 2008 and run through 2009.

Within lessons of Marketing of services, Silesian University in Opava, OPF in Karvina made the marketing research concerning companies providing services in 2010. The aim of the research was to discover whether and how the economic crisis affects marketing strategies (that are presented by elements of marketing mix). For purposes of this article we have chosen companies involved in the tourist trade development, i.e. companies providing services in hotel industry, accommodation and tourism. In total 74 companies took part in the research. Data achieved in the research are related to the time period of beginning of the crisis, i.e. year 2009. 
Tourist trade is a cross-sectional industry that includes many different services and professions and it is connected to many other economic activities. This branch of the tertiary sector composes more than a half or nearly two-thirds of economies of advanced industrial countries.

Economic crisis affected the boarding and lodging segment the most notably. Numerous Czech accommodation facilities faced essential problems and were forced to discharge the employees or to bankrupt. Nevertheless, the crisis also sorely affected other sectors of tourism, such as coach companies, that sell busses, incoming travel agencies and restaurants and gift shops that were due to decrease the number of employees or to go to bankruptcy ${ }^{1}$.

\section{Characteristics of service sector marketing}

Marketing of the tertiary sector, due to specific characteristics of services that differ from tangible commodities, is an inhomogeneous group of activities and varies according to the character of provided services, the size and activities of the organization that provides these services.

To differentiate commodities and services, several numbers of characteristics are used. The most common characteristics are: immateriality, destructibility (i.e. the impossibility to store the services) and inseparability of the service consumer from its provider. As a result of these specifications an extended marketing mix has been developed. This mix composes of traditional elements, i.e. product, price, place, communication and is added to elements that approach the service to its customer and make the product visible. These are people, processes and material environment. ${ }^{2}$

The marketing strategy of the product is engaged in the life cycle of service, enlarging or reducing the service range and launching of new services to the market. The price strategy in the tertiary sector is a result of many factors. Aims of the organization, the character of services that are provided, costs and strength of its competitors in the market are the most important. Definitely, the company has to react to inconsiderable external environment impacts among those we can also consider symptoms of global economic crisis.

Likewise accessing services by their customers is managed by different rules than sale of goods. The tertiary sector uses mostly direct distribution channels; involvement of an intermediary is less often. The choice of intermediaries is affected especially by the character of the service, comfort and needs of customers and distribution costs.

Attention that the company has to pay to its marketing communication strategy how to communicate with its customers, otherwise to its communication mix, is necessary for the tertiary sector marketing, especially because it is an immaterial product that shall be approximated to its user and by this way to decrease his uncertainty of choice and purchase of a service. Traditional tools of communication mix, such as advertisement, promotion, personal purchase and Public relations are nowadays added to modern forms of internet communication, direct marketing and other ways of marketing communication.

\footnotetext{
${ }^{1}$ OFOWORLD.CZ. Nad cestovním ruchem zataženo.[online].[citováno 2011-06-04]. Dostupné z:

< http://cfoworld.cz/ostatni/nad-cestovnim-ruchem-zatazeno-44>

${ }^{2}$ VAŠTÍKOVÁ, M. Marketing služeb efektivně a moderně. Praha: Grada Publishing, 2008. ISBN 978-80-2472721-9
} 
Inseparability of the service from its provider is the main reason to add an element "people" into marketing mix. The quality of the service is classified by the customers especially through behaviour and acting of so-called contact persons with whom they are in the direct contact while the service is provided. The organization has to pay attention to its personnel policy even during economic crisis. The employees have to be chosen carefully, educated, motivated and led.

The environment largely participates on materialization of services for their customers. It means common effect of appearance of the facilities up to the atmosphere of the place that is perceived with all senses the client has. To make an atmosphere usually music, smell, visual and haptic percept is used. Material environment of services has the effect on both customers and employees feelings and percept. The systematic control of material environment and its strategy creates image of the organization, differentiates it from its competition and holds information about the service itself.

One of the most important issues to be solved by strategic management of the service rendition is a capacity control. Capacities of the organization shall be in accordance with a service demand. The demand can be affected by the organization by means of different tools (such as efficient promotion) or include automatization (automatization support) into the service rendition process.

It is obvious that in the situation when the supply of competitive companies providing services in the market predominates, it is the customer who chooses the company that offers high quality services which not just meet his requirements but also exceed them. Therefore companies providing services should make research of the quality level of provided services including customers' opinions (by means of questionnaires for example).

\section{Marketing research}

As mentioned in the introduction, we made marketing research concerning random selected companies providing services in hotel industry, accommodation and tourism in 2010. The aim of the research was to discover what steps the companies take to face the economic crisis. With our questions we focused on possibilities offered by portfolio of marketing mix tools and elements.

\subsection{Conclusions of the research}

In the tourist industry there are 15 companies represented and 59 companies in the hotel and accommodation industry. See their structure below in Tab.1. 
Tab.1: Structure of provided services

\begin{tabular}{|l|c|r|}
\hline Provided services & $\begin{array}{c}\text { absolutely } \\
\text { (number) }\end{array}$ & $\begin{array}{c}\text { relatively } \\
\text { ( \% })\end{array}$ \\
\hline hotels & 13 & $22 \%$ \\
\hline hospitality & 19 & $32 \%$ \\
\hline gastronomy & 22 & $37 \%$ \\
\hline fast food & 1 & $2 \%$ \\
\hline tea-room & 4 & $7 \%$ \\
\hline In total & 59 & $100 \%$ \\
\hline
\end{tabular}

As for the company's seat, most of the companies i.e. $50(67,6 \%)$ are from the MoravianSilesian region, then the second most often seat is from the region of Olomouc with 11 companies $(14,9 \%)$, then the region of Zlín with 5 companies $(6,8 \%)$. There is one company from following regions represented in the research: South Moravia, Pardubice, Vysocina and Prague. There are also 4 companies included from Slovakia (the region of Žilina).

From the total number of interviewed companies dealing in tourisms, there are 14 companies $(18,9 \%)$ on the market for longer than 5 years and one less than 5 years (from 2 to 5 years). By contrast, we have various life-times within companies in hotel and accommodation industry. See Fig.1 that follows.

Fig.1: Survey of the number of companies within hotel and accommodation industry as for the time they are active in the market

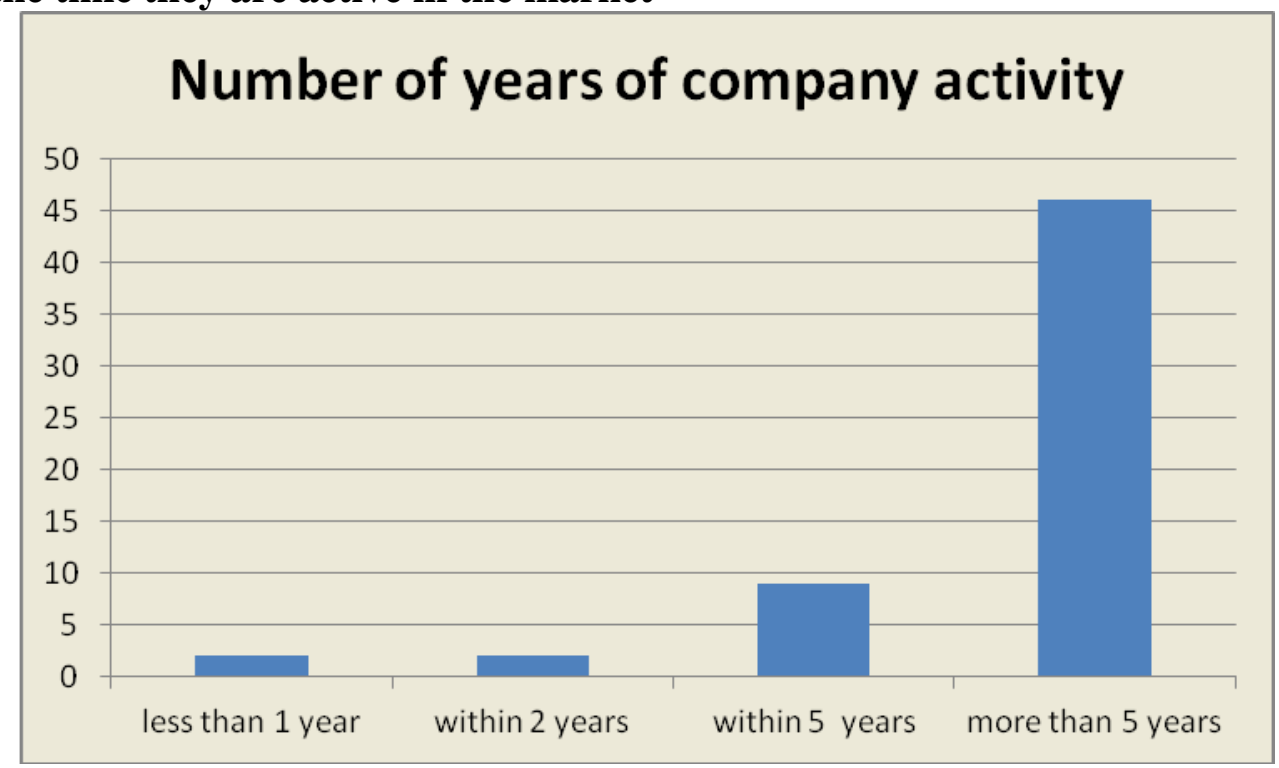

46 companies $(62,2 \%)$ are active in the market for more that 5 years, 9 companies $(12,2 \%)$ are in the market between 2 to 5 years and 2 companies are active up to 2 years and less than 2 years. We can say that these numbers show evidence of more remarkable turbulence in the industries.

Several characteristic differences may be found among interviewed companies with regard to the number of their employees. Companies from tourist industry are so-called microcompanies (up to 10 employees), see Tab.2. On the other hand companies in the hotel and accommodation industry have more diverse employment bases. There are both small 
companies (10 - 49 employees) as well as one middle-size company having more than 50 employees. However, the core is also created by micro-companies (See Tab.3).

Tab.2: Number of employees in companies from tourist industry

\begin{tabular}{|l|c|r|}
\hline $\begin{array}{l}\text { Number of } \\
\text { employees }\end{array}$ & $\begin{array}{c}\text { absolutely } \\
\text { (number) }\end{array}$ & $\begin{array}{c}\text { relatively } \\
(\mathbf{\%})\end{array}$ \\
\hline $0-9$ & 12 & $80 \%$ \\
\hline $10-49$ & 2 & $13,3 \%$ \\
\hline $50-$ more & 1 & $6,7 \%$ \\
\hline In total & 15 & $100 \%$ \\
\hline
\end{tabular}

Tab.3: Number of employees in companies in hotel and accommodation industry

\begin{tabular}{|l|c|c|}
\hline $\begin{array}{l}\text { Number of } \\
\text { employees }\end{array}$ & $\begin{array}{c}\text { absolutely } \\
\text { (number) }\end{array}$ & $\begin{array}{c}\text { relatively } \\
(\mathbf{\%})\end{array}$ \\
\hline $0-9$ & 33 & $56 \%$ \\
\hline $10-49$ & 25 & $42 \%$ \\
\hline $50-$ more & 1 & $2 \%$ \\
\hline In total & 59 & $100 \%$ \\
\hline
\end{tabular}

The main aim of our research was to find out how the companies change their strategies under conditions of the global economic crisis. At first we were interested whether and how the companies react to the crisis by changing the service, i.e. the product.

Companies acting in tourist industry mostly enlarged offers of their services ( 8 companies). 7 companies did not change the offer of their services. The situation among companies in hotel and accommodation industry is shown in Tab.4.

Tab.4: Changes in offers of services in companies in hotel and accommodation industry

\begin{tabular}{|l|c|c|}
\hline $\begin{array}{c}\text { Changes in offer of } \\
\text { services }\end{array}$ & $\begin{array}{c}\text { absolutely } \\
\text { (number) }\end{array}$ & $\begin{array}{c}\text { relatively } \\
(\mathbf{\%})\end{array}$ \\
\hline Reduction & 1 & $2 \%$ \\
\hline Extension & 26 & $44 \%$ \\
\hline Without change & 32 & $54 \%$ \\
\hline In total & 59 & $100 \%$ \\
\hline
\end{tabular}

Investigating how the companies focused on the extended offer of services we have found out that 22 companies $(29,7 \%)$ aimed at contacting the new segment of customers, 10 companies, i.e. $13,5 \%$ target new destination to travel to and 51 companies $(68,9 \%)$ offered brand new services. It gives evidence that the new situation of economic environment accelerated the innovative process of the product offered by interviewed companies.

The approach to price policy of the companies is more conservative. Most of the companies made no change of the price strategy - 46 companies $(62,2 \%)$. We noticed the change of price in 28 of interviewed companies $-14(18,9 \%)$ in the direction to increase and $14(18,9 \%)$ in the direction to decrease the price. 
Distribution of services is done directly in most cases. Sporadically we can find combination of direct distribution and distribution through an intermediary. Some of services, especially catering, need to reach their customers themselves. With regard to the crisis, no modification of distribution was made by interviewed companies.

The situation differs for elements of marketing communication of companies. We were interested to understand whether advertisement was a part of economy measures, whether the companies understand importance of internet communication and whether their web pages are created and functional. We concerned whether other tools than just the advertisement are used in marketing communication of the companies as well.

We were surprised to realize that 17 companies (23\%) confirmed limitation of advertisement, especially when understood that 7 from them were acting in tourism.

$61(82,4 \%)$ of interviewed companies have their own web pages. Most of the companies that do not have their web pages act in catering.

Information about possible ways how to promote their services used by companies in tourist industry is given by Fig.2.

\section{Fig.2: Means of communication with customers in tourist industry}

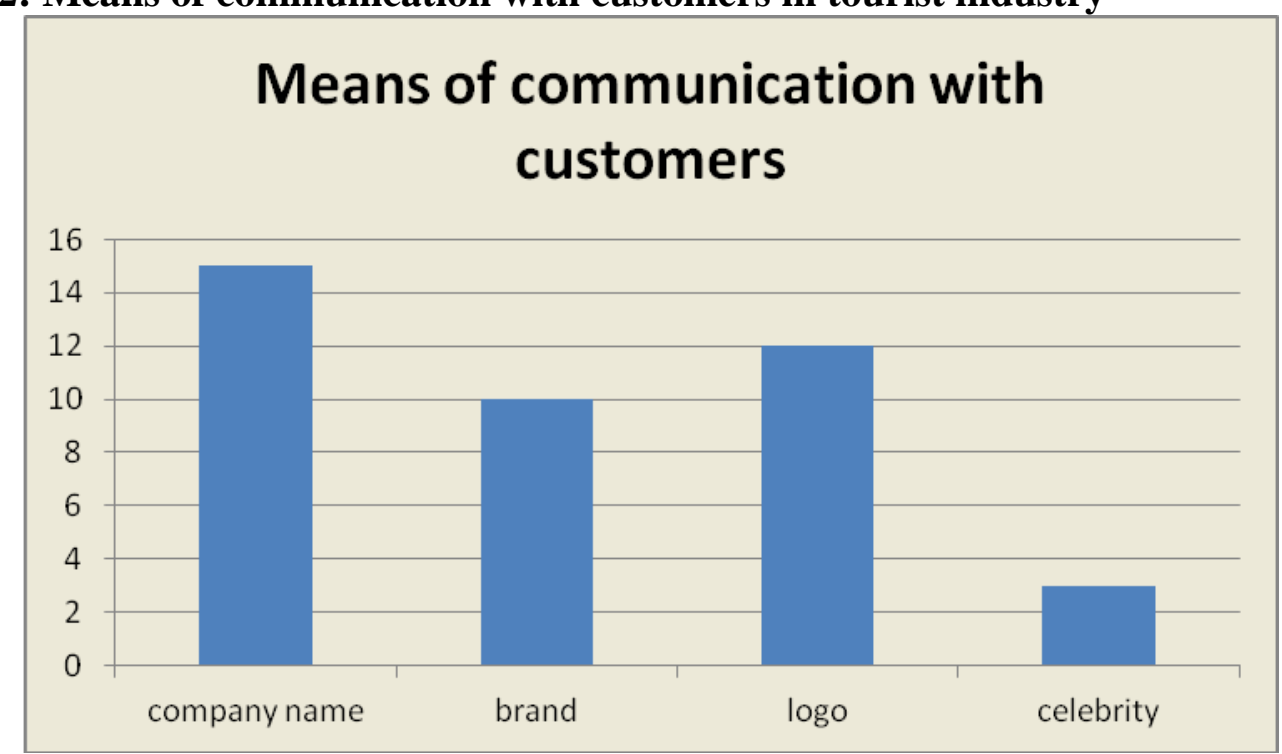

All the companies use their names in the communication with customers. Furthermore 10 companies use company brand and 12 companies in tourist industry have their own logo. It may be interesting to say that 3 companies use a celebrity to promote their products.

The situation differs a little in hotel and accommodation industry. Only 52 companies $(88,1$ $\%)$ uses their name in the communication with customers. Again we have discovered that 8 companies take an advantage of using a celebrity as a way how to communicate with their customers. 36 companies use their logo and 30 have their own brand. Two companies mentioned direct marketing as a different option and one company mentioned sponsorship of cultural events. 
As one of useful tools against the crisis efficient and consequent work with human resources (HR) is considered. In the tertiary sector we talk about people instead. We have also focused on this issue in our research and tried to discover which steps in HR the companies took.

Steps taken by companies in tourist industry are clearly shown in Fig.3. The questionnaire allowed the companies to choose more that one reply. While investigating the effect of crisis on HR, 3 companies limited training of their employees based on commercial principle and in singles the companies mentioned that they had decrease number of employees and decrease salaries. 10 companies in total made no changes at all.

Fig.3: HR steps taken by companies in tourist industry

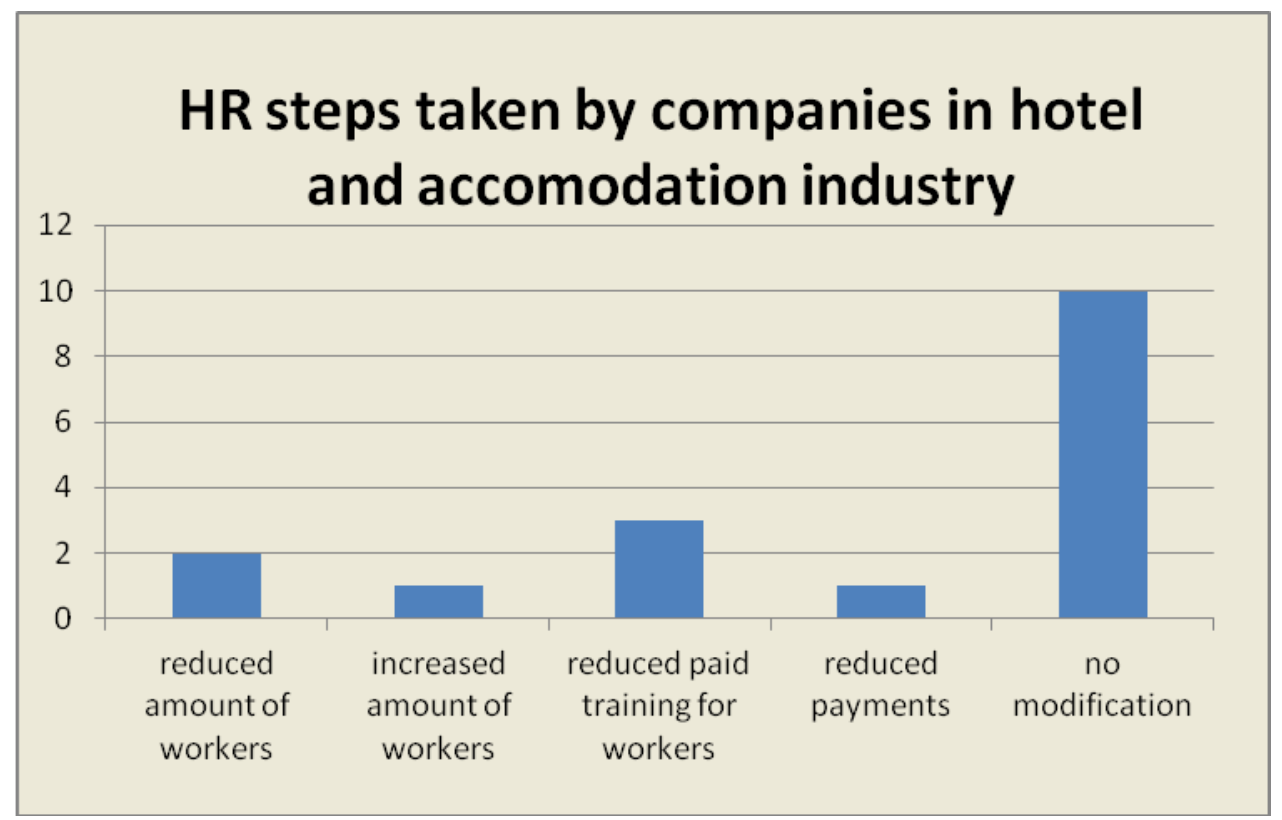

Steps taken by companies in hotel and accommodation industry are shown in the following Fig.4.

Fig.4: HR steps taken by companies in hotel and accommodation industry

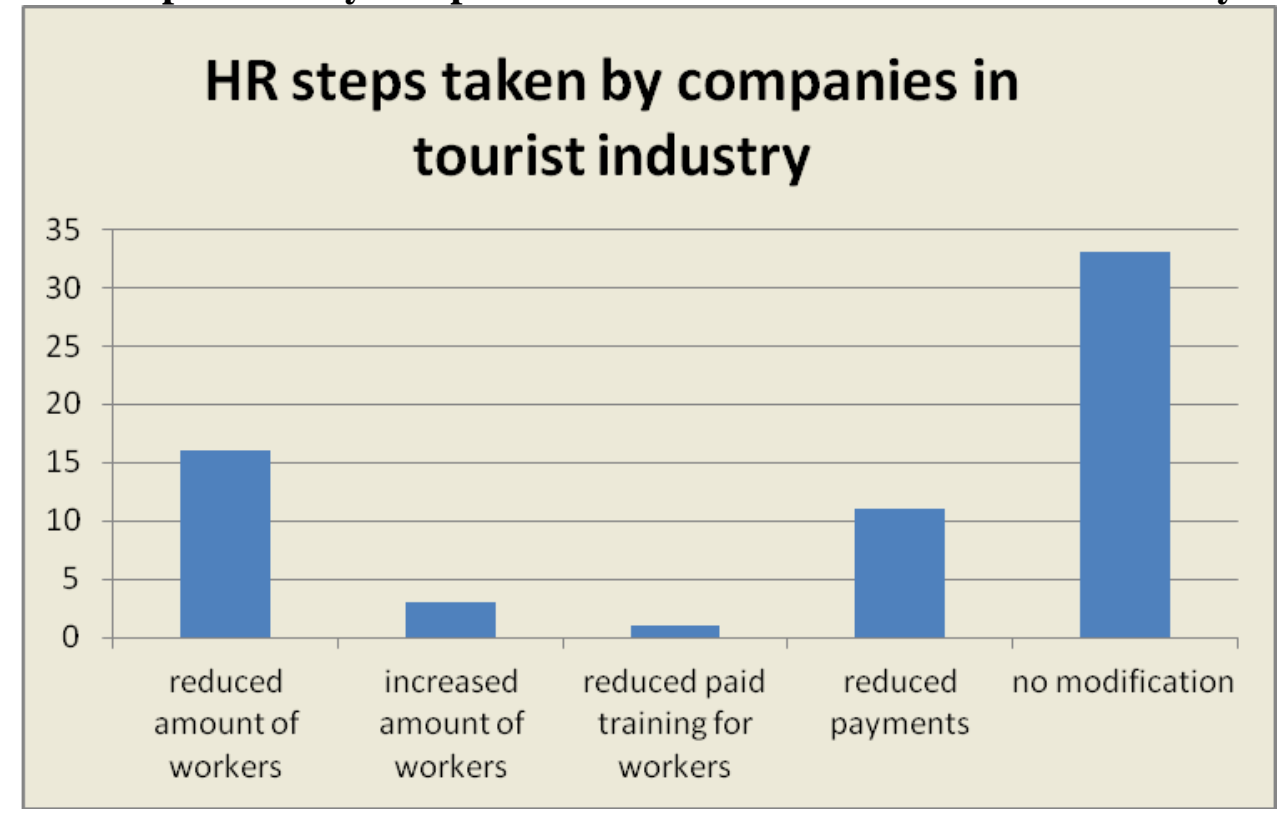


Also in hotel and accommodation industry whole 33 companies took no steps $(55,9 \%)$. However, there are 16 companies which decreased the number of employees, 11 companies which decreased salaries and just one company which limited training of their employees provided on commercial base. There are also 3 companies which increased the number of their employees.

The research did not confirm that the prime area of "anti-crisis" steps is in HR management. Whole 43 companies $(58,1 \%)$ from all interviewed companies made no change or modification of their HR policy. We can just anticipate that the reason is that there are mostly small and micro companies in chosen areas that find no space for further savings in the field of the number of employees or their salaries.

Small modifications of working hour restriction were done by 6 companies $(8,1 \%)$ only. These were from catering.

Another recommended action how to eliminate the impact of the crisis is limitation or postponement of material investments. This action was taken by 51 companies in our research $(68,9 \%) .9$ of them are active in tourism $(12,2 \%)$. To be specific, these investments were done into new furniture and equipment in their facilities.

One of interesting, however not often used a tool of marketing mix in services, is the process of the service providing itself. Regarding this area we concerned whether the companies use the system of reservations or not. According to our expectation, the use of reservation systems is very often. Only 9 companies $(12,2 \%)$ do not use them. Most possibly they are small companies providing catering.

Another tool that may be used by companies to improve provided services and be more competitive is to learn about how the customers are satisfied with their services. Knowledge and use of these data can be considered to be another action how to face the crisis and battle with it even by small companies. 33 of the interviewed companies $(44,6 \%)$ do not try to understand how the customers are satisfied with their services. 5 of these companies act in travel industry, 28 in hotel and accommodation industry.

Although the ratio of companies which make no research about their customers' satisfaction is quite high, this fact is in accordance with the tertiary marketing theory. We can see practically one of typical characteristics of services - i.e. inseparability of the service from its provider. The consequence of this characteristic is that the service provider gets an immediate feedback about his customer satisfaction. This describes why so many of interviewed companies, especially from catering, do not consider this research to be important for them.

The final question of our questionnaire was open to let the companies express themselves which of taken steps and actions they consider to be the most efficient against the economic crisis.

We got 36 replies in total (48,6\%); 30 from companies acting in hotel and accommodation and 6 from tourist industry.

The most common were replies mentioning price policy (decrease of prices, time limited price reductions), then the decrease of number of employees follows. It is related to higher labour productivity evaluation. Also enlargement of portfolio of services and targeting on new 
segment of customers was appreciated by the companies. The interviewed companies understand importance of the service quality as well as good advertisement.

\subsection{Summary of key results of the research}

- $77,9 \%$ of companies dealing within hotel and accommodation industry are activ over 5 years in the business.

- Services of tourist industry $(53,3 \%)$ seem to be more active in regard of modification of an offer of their products, mostly offering new destinations. Also companies within hotel and accommodation industry react to the crisis by enlargement of their offer of products/services $(44,1 \%)$.

- Approach to the price policy makes a statement on conservatism of the companies because most of interviewed companies $(62,2 \%)$ do not modify their price policy in any way.

- A negative finding is that 17 companies (23\%) choose as one of the ways how to reduce costs, reduction of advertisement. It is a startling statement that 7 of the 17 companies acts in travel industry. We cannot but guess that more than an absolute limitation of advertisement it means that tools of communication are chosen more effectivelly.

- 41 (i.e. $58,1 \%$ ) from the total number of interviewed companies make no changes of their HR policy.

- Total number of 51 companies $(68,9 \%)$ from which 9 companies were from tourist industry, confirm that they postponed material investments into their facilities.

- Research about their customer's satisfaction is made by $55,4 \%$ of the interviewed companies only. The result is most probably effected by small companies within hotel and accommodation industry.

\section{Conclusion}

The research has come with several positive findings. For example the one, that at the time of crisis it is good to keep active and to face the crisis by innovating the own product (services). It is important to focus on the quality of provided services and build a good name of the company. A competitive advantage may be evident in decrease of costs (and salaries for example) or postponement of material investments. In such way we cannot consider these actions to be positive only, otherwise the decrease of number of employees is compensated by the increase of labour productivity and postponement of investments is motivated by a serious study and is limited in time.

Negatively we can see especially restrictions of some of the tools of marketing communication, mostly advertisement. 


\section{Literature:}

[1] VAŠTÍKOVÁ, M., Marketing služeb - efektivně a moderně. Praha: Grada Publishing, 2008. ISBN 978-80-247-2721-9.

[2] OFOWORLD.CZ. Nad cestovním ruchem zataženo.[online].[citováno 2011-06-04]. Dostupné z:<http://cfoworld.cz/ostatni/nad-cestovnim-ruchem-zatazeno-44>

JEL M31, M39

\section{Ing. Miroslava Vaštíková}

Odborný asistent Katedra marketingu

Obchodně podnikatelská fakulta Karviná

Slezská univerzita Opava

Univerzitní náměstí 1934/3, 73340 Karviná

Tel.: 596398264

vastikova@opf.slu.cz 